\title{
CHAPTER SIXTH.
}

\section{REPORTS OF COL. OSTERHAUS AND GENERAL ASBOTH, 1ST AND 20}

\section{DIVISIONS.}

\section{OSTERHAUS.}

CAPTAIN:-In compliance with special orders from headquarters of South West District, I have the honor to report on the part taken by the 1st Division, in the three days battle of the 6th, 7th and 8 th of this month.

At 9 o'clock, P. M., on the night of the 5 th inst. (I was then stationed at McKreisick's farm, 3 miles south-west of Bentonville, Arkansas) I was officially informed of the approach of the enemy, receiving, at the same time, orders to march at $2 o^{\prime}$ clock, A. M., next morning, in order to join the other Divisions of the army at Pea Ridge, on the Fayetteville or telegraph road. We left camp at the hour mentioned, and arriving at Bentonville, General Sigel ordered the 12th Mo. Vols., Major Wangelin commanding, to remain there and reinforce the rear guard (composed of the $2 d$ Mo. Volunteers, Col. Schæfer, the Flying Battery, and the Fremont and Benton Hussars). This force was to stay at Bentonville, under the immediate command of General Sigel, while I myself proceeded to Sugar Creek with the other regiments and batteries of the 1st Division. On my arrival there, I learned by rumor, afterwards confirmed officially, that General Sigel had been attacked at Bentonville, and that his egress from that town was disputed by a strong rebel force. I immediately, after giving notice to General Curtis, ordered all the regiments and Capt. Hoffman's Battery to return with the utmost speed to the support of our General. They, together with the 15th Mo. Vols., of the $2 d$ Division, responded promptly to my sudden call, and though tired by a 16 miles march, hurried back in double quick to the field of action.

I had almost arrived at the head of Sugar Creek Hollow with this foree, when I met General Sigel and his small force, who had broken through the enemy. The latter was still following them. On a bend, in the narrow defile formed by Sugar Creek Hollow, I planted two pieces of Hoffman's Battery, while the 15th Mo. Vols. (2d Division) formed in a line of battle in support of the Battery, while the 17th Mo. Vols. were deployed as skirmishers over the whole breadth of the valley and the crest of the bordering hills.

The enemy advanced towards us with artillery in the valley and skirmishers on the hills, when a few rounds of spherical case and cannister stopped him. His artillery played without success. I then ordered the two pieces back, as well as the infantry, with the exception of the 17th Mo., which covered our retreat in most admirable style, exchanging an occasional shot with the enemy. Major Poten, commanding the 17th Mo., deserves the highest credit for the determination and coolness exhibited on this occasion.

We arrived in eamp without any further molestation, and prepared to bivouac on the northern ridges skirting Sugar Creek Hollow, near the camps of the other Divisions, fortifying our position at once, anticipating \& night attack. The enemy did not molest us however. 
MARCH 7TH.-Early morning brought us the intelligence, that the united forces of the Confederate and Mo. rebels had passed our right flank, and were deploying also on our line of retreat, near Elk Horn Tavern. They advanced during the night by the direct road leading from Bentouville, Ark. to Cassville, Mo. (This road joins the Telegraph Road from Fayetteville to Cassville, at a point a few miles north of the above mentioned Elk Horn Tavern).

To prevent the enemy from still more strengthening their position in our rear, and to engage a part of his force, General Curtis ordered me to make a demonstration on their right flank, toward Leetown, and if necessary, of the Bentonville and Cassville road. The forces detailed for this purpose, were mainly cavalry (Bailtalions of the 3d Iowa, 1st and 5th Mo. Cavalry) and three pieces of the Flying Battery, all under the immediate command of Col. Bussey, 3d Iowa Cavalry, and further the 12 th Mo., 36th Ills. and 22d Indiana regiments, three pieces, 12 pound howitzers, of Capt. Welfley's Battery, and Capt. Hoffman's Battery. 'This command started after ten o'clock, A. M. I arrived at Leetown, haring no knowledge whatever of the whereabouts of the enemy, and took position in the open fields north of Leetown, going forward myself with the cavalry and three pieces of the Flying Artillery. The field in which the artillery and infantry were posted, is divided from another tract of cultivated ground, by a belt of timber with thick undergrowth. Debouching from this timber, I came in sight of a large force of the enemy, mostly cavalry. All the open fields to my froni and right were occupied, and the road from Bentonville was filled with new regiments'arriving.

As appears from the accompanying sketch; this gathering of the enemy's forces was accomplished in the immediate neighborhood of the headquariers of our army, being only $1 \frac{1}{2}$ miles distant, and it was patent that the enemy was preparing a most energetic attack on our right flank, at the same time they opened fire on our rear. Notwithstanding my command was entirely inadequate to the overwhelming masses opposed to me-which, I learned afterwards, were under the immediate command of Generals McCulloch and McIntosh, and comprised some of the very best drilled regiments in the Confederate service, and Indian regiments - I could not hesitate in my course of action. The safety of our position was dependent on the security of our right flank, and the keeping back of the enemy until I was reinforced.

I therefore ordered the three pieces of the Flying Battery to form, supporting them by companies from the 1st Mo. Cavalry (provided with revolvers and revolving carbines) forming the remainder of the cavalry in line of attack.

The Battery opened fire with the most disastrous effect on the enemy, and in order to cut off fresh supports, two companies of cavalry were ordered to charge down the road. When I saw the effect of the artillery creating a panic in the lines of our opponents, I ordered Col. Bussey to charge from the right, attacking the left of the rebels.

While these preparations were making, a wild, numerous and irregular throng of cavalry, a great many Indians among them, rushed towards us, breaking through our lines. A general discharge of fire-arms on both sides, created a scene of wild confusion, from which our cavalry, abazdoning the three pieces of 
artillery, retreated towards their old camping ground, while that of the enemy made their way across fields toward the Bentonville road.

It being evident that the cavalry could not be formed again for the present, I had to rely solely on the infantry and artillery to achieve my purposes. Fearful of the impression which the above scene of confusion might have made, I went to meet them. They had stood without flinching, and in a few minutes they were in such shape I could attack the enemy again.

The 22d Indiana on my right, Capt. Welfley's two pieces (one piece had been disabled) the 12th Mo., Captain Hoffman's Battery and the 36th Hls. on my left, formed the line. For reserve, I had to rely on reinforcements, for which I sent to General Curtis.

The enemy soon made his appearance with colors flying on the opposite side of the field which I occupied. Our batteries opened their fire on him, sweeping everything from our sight. I ordered skirmishers from the 12th Mo., to advance and scour the woods on our right and front, and sent one company of Benton Hussars (which had reassembled) to our loft.

On approaching the woods, they were received by the enemy with a heavy musketry fire, to which the infantry replied so successfully, that they were able to bring back (from a very exposed position) the piece of Capt. Welfley's Artillery which had been disabled. This piece afterwards did very good service.

For several hours the enemy repeatedly attempted to advance, on each occasion bringing fresh troops into action; however, they invariably had to give way to the unflinching courage of my men.

McCulloch and McIntosh led their troops in person, and both fell. The former from a ball from a soldier of the 36th Ills. Volunteers-Peter Pelican.

The enemy's cannon played from time to time pretty severely on our ranks, and it became necessary to silence them. My instructions to that effect were so well executed, that the rebels were unable even to carry away the three pieces of the Flying Artillery abandoned by our cavalry in the early part of the day. They had to leave them on the field.

About 2 o'clock, P. M., General Jefferson C. Davis arrived with some of his regiments, and was joined by the $22 d$ Indiana, up this time under my command.

The gallant officer deployed his regiments at once on my right, advancing towards any foe who might still be in the timber. The report of musketry told me a lively fight was going on.

To act in concert with him, I ordered my right forward to front, also some cavalry which had partly reassembled. I advanced with my whole line, when the enemy showed his colors again. Cavalry and infantry came around the left of General Davis and opened their fire on my now unsecured right. In double quick, I threw the 12th Mo. on this exposed flank, supporting them by Capt. Welfley's Battery, who had wheeled to the right, and forming the 36 th in close column, on the extreme left of this new position, to be ready for any cavalry attack, protecting at the same time Capt. Hoffman's Battery.

The enemy's plan being defeated by a raging fire from the 12 th Mo. and Capt. Welfley's Artillery, they made a feeble attempt to cut off our line of retreat, which was frustrated by skirmishers thrown out by the 36 th Ills. Vols. 
As my infantry force was not equal to the artillery (having only the 12 th and 36 th with me) and also to counteract any further attempts of the enemy to outflank me, I thought it judicious to send four pieces of Capt. Hoffman' s Battery back to Leetown, which affords a very commanding position. This with some of General Davis' infantry, formed my reserve.

Cavalry flankers and infantry skirmishers, having thoroughly scoured the ground in front of where the battle had raged for hours, reported the enemy gone, and his train could be seen in the distance, moving toward Bentonville.

Similar news was brought to me from the right, where a brave Indiana regiment (Col. Davis') held aloft the stars and stripes, which emblem of our country was hailed with enthusiastic cheers by the men around me.

General Sigel now arrived with the rest of the 1st and $2 \mathrm{~d}$ Divisions, and as we passed over the ground, the enemy's dead and wounded, amounting to hundreds, gave evidence of the fearful execution done by our soldiers. On our extreme right, where Col. Carr was engaged, the cannon were still thundering, although night was not far distant. We marched to the assistance of our friends, planted our battery and bronght the infantry into line, but it was too late to open fire.

General Sigel was of the opinion that it was best to wait until morning, and not to betray our position by a few shots, which could be of no avail, as it was already night. Our men lay down to rest in a wet cornfield, having eaten nothing since morning, but not a murmur was heard; they waited in patience.

So ended the second day of battle. I cannot pass over the occurrences of this day without again paying tribute to the indomitable courage and devotedness of officers and men. They deserve the highest enconiums for their bravery and endurance; to mention names is almost impossible, when everybody has such noble claims.

Under my immediate observation, were all the artillery officers present; Capt. Welfley, the unterritied, and Lieut. Benecke, both of Battery A, and Capt. Hoffman and Lieuts. Frochlich, Piteret and Frank, of Battery B (Ohio) Major Wangelin, commanding 12th Mo. Vols., and Col. Greuisel, of the 36th Ills. Vols.; furthermore, two reliable officers, who were detailed to me for the occasion as orderly officers, viz: Capt. Kielmansegge (Fremont Hussars) of General Sigel's staff, and Capt. Anlefeldt (12th Mo. Vols.) of General Curtis' staff, and also the gentlemen of my staff. I have also to mention Capt. MeKenny, Asst. Adjt. Gen'l on General Curtis' staff, who was with me part of the day, aud rendered great assistance in bringing Hoffman's Battery to Leetown, as well as the general arrangement for the disposition of my lines.

MARCH 8TH, 1862. - The commencement of this day, still found our troops on the cornfield, without food or fire. Several messengers, sent off for provisions, returned, having been unable to procure them. It being indispensable that our men should eat something before entering on another day of struggle, General Sigel, at 2 A. M., gave the order to return to camp (about one mile distant) where we arrived at 3 A. M. The men slept until daybreak, and provisions having been brought up in the meanwhile, fell in after a hasty breakfast to deliver another and last blow on the enemy. 
The ground selected for this last attack, by Lieut. Assmussen (of General Sigel's staff) was a field forward of, and connecting with, the one on which we had taken position during the fore part of the night.

The 44th Ills. regiment was first brought up and formed in line on the left of the right wing ( $3 d$ and 4 th Divisions) of our army. General Sigel then arrived and took command in person, while I was engaged in bringing out the regiments and batteries of my Division.

The first position on the field was as follows:

The 25th Tlls. Vols. on my extreme right, connecting with the left of the right wing of our army ( $3 \mathrm{~d}$ and 4 th Divisions). On the left of, and in advance of that regiment, I had posted the 44th Ills. Vols., with Capt. Welfley's Battery on their left. To the left of the Battery, the 12th Mo. Vols. was brought into position, while the 36 th Ills. Vols. formed the extreme left, in column by Division at half distance, Hoffman's Battery oecupying the interval between the 12th Mo. and 36th Ills. Vols. The $3 d$ and 17 th Mo. Vols. were formed as reserve in rear of my centre.

The enemy fired from several batteries with the utmost vehemence, their shot and shell falling thickly around our lines and on our batteries; so much so, that the troops on our left were forced to fall back for a while. At this critical moment, the batteries of the 1st Division opened on the enemy, bearing mainly on the extreme right of the rebels. The effect was proportionate to the skill, courage and coolness of officers and men. The enemy, seeing that his right was endangered, concentrated all his energies on that wing, the fire of their other batteries slackening off considerably. General Sigel ordered the batteries to advance, and at the same time dispatehed me to report progress. By this movement, in which the right wing of our army co-operated, the enemy's entire line of retreat was brought under the eoncentrated fire from our lines.

To execute this movement, on my return all our batteries wheeled to the left, and I ordered the skirmishers of the 12 th Mo. Vols. forward towards a grove of timber, from which the heaviest battery of the enemy was firing against us. The men under the gallant Capt. Lightfoot, of Company F, advanced like veterans. In connection, and to the left, the skirmishers of the 36th and 44th Ills. Vols., were also thrown out, and all the regiments of the lst Division began their march forward, in support of the skirmishers. They were received with an intense fire by the enemy. The 12th Mo., supported by the 25th Ills. (Col. Coler) entered the grove on our right, where the enemy's infantry fired heavy volleys, disputing every inch of ground.

Major Wangelin, commanding 12 th Mo. Vols., here had his horse shot under him, and the two regiments going on in gallant style, soon obtained possession of the main road.

Two brass pieces and the flag of the Dallas Artillery were taken by the 12th Mo. in this charge.

During these struggles, the movements on our extreme left were just as fast, powerful and successful. The 17 th and $3 \mathrm{~d}$ Mo. and the 36th Ills., supported by the gallant soldiers of the $2 d$ and 15 th Missouri, and the artillery of Lieut. Chapman, 2d Division, advanced steadily-the cavalry on the left towards the rocks 
over which the enemy was retreating. Soon we saw the noble regiments, 17th and $3 \mathrm{~d}$ Missouri, and 36th Ills., on the crest of the steep rocks, and with this position, the field of the defeated rebel army was in our possession. We had conquered.

The rebels were retreating in all directions; one force by the Cassville road, which we followed in close pursuit, and prevented every attempt of theirs to form again. A great many prisoners and munitions of war, muskets, caissons, baggage wagons, and one more cannon, were taken by us in this pursuit.

General Sigel ordered me to drive the rebel column as far as Keetsville, which $I$ did, arriving in the neighborhood of that place at $50^{\prime}$ clock, P. M.

Next morning, March 9, we entered the town of Keetsville, and dispatehed a cavalry force a few miles beyond, but it being evident the enemy's forces in that direction had dispersed, General Sigel ordered us to return to the battle ground, when we encamped near our comrades of the other Divisions.

In conclusion, I ought to add the list of names of those who excelled.

They all were brave, and I only could repeat the names mentioned before. 1st Lieut. Jacobi, of Capt. Welfley's Battery, who was not in the battle of Leetown, did great service and immense execution with his twelve-pound guns on the 8 th, and he is a worthy comrade of his brother officers.

It also becomes my pleasant duty to acknowledge the very kind assistance I repeatedly received on the 8 th from Col. Schæefer, 2d Mo. Vols., and his command.

Herewith, you will find the reports of the different regiments and batteries comprising my command. The list of easualities was previously sent in. All of which is respectfully submitted.

\section{P. J. OSTERHAUS,}

Col. Comd'g lst Division, Army of the S. W.

To Capt. T. I. McKenny, A. A. Gen'L S. W. Dist. ArMy of the Mo.

THE LOSS OF THE FIRST DIVISION.

\begin{tabular}{|c|c|c|c|c|c|c|c|}
\hline \multicolumn{2}{|l|}{ Regiment or Corps. } & \multicolumn{3}{|c|}{ Commissioned Officers. } & \multicolumn{3}{|c|}{ Enlisted Men. } \\
\hline & $\begin{array}{l}\text { Men in } \\
\text { Action. }\end{array}$ & Killed & Wounded. & Missing. & Filled & Wouded. & Missing. \\
\hline 18t Brigade. & & & & & & & \\
\hline (17th Inft'y Mo. Vols. & & (.............. & ........ & & & …...........1 & $\ldots . .9$ \\
\hline 25 th " " Ills. " " & $\ldots 400$ & , .............. & 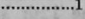 & (.............1 & ….........3 & ...........17 & …..........1 \\
\hline $2 d$ Brigade, Col. Greuisel. & ........ & $\cdots$ & 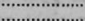 & ( n................ & (n.............. & ............2 & ...........17 \\
\hline 12th Inft'y Mo. Vols. & ................... & & (........ & & (... & …….........28 & (…........2 \\
\hline 36 th " Ills. " & ..........830 & (.............. & & $\ldots .1$ & $\ldots . .3$ & ...........32 & ...........30 \\
\hline Welfley's Bat. Mo." & & & a.c...... & (n............. & n..........1 & ............6 6 & (................. \\
\hline [ Hoffman's " " & & & ......... & & & ............1 & \\
\hline Osterhaus' Staff [Ordl'y] & & & & & & & |............... \\
\hline Total, & .... & & ....... & $\ldots . .2$ & .........10 & .............88 & |.........68 \\
\hline
\end{tabular}

ASBOTH.

Head Quarters 2D Division,

Camp at Elk Horn Tavern, Pea Ridge, Ark., March 16, 1862. ? Gen'l F. Sigel, Commanding 1 st and 2d Divisions:

General:-In compliance with Special Order No. 163, I have the honor to submit my report of the participation of the $2 d$ Division in the battle of the 6 th, 
7th and 8th days of the present month at Bentonville, Sugar Creek and Pea Ridge.

By way of preliminary, I may allude to the happy union of the 1st and $2 \mathrm{~d}$ Divisions under your command. I say happy union, because I have never witnessed more perfect harmony, either in camp or upon the battlefield. Native Americans and foreigners of varied nationalities have been aptly blended, and the fraternity of the troops finds its counterpart in that prevailing between the officers and commanders. No wonder the privations of our arduous winter campaign, in the midst of a hostile populace, were so cheerfully borne, or that the hardships thus engendered, should result in so irresistable a co-operation upon the battle-field.

Officers and men were all imbued with the earnest. feeling, that you would lead them only to victory. And you did so, at a moment when experienced and brave soldiers admitted the eritical chances of our position.

Allow me to thank you, General, in the name of my Division, for your skillful leadership and the result achieved.

ThURSDAY, MAROH 6TH, 1862.-On the 5th of March, being encamped at MeKreisick's farm with my Division, in close proximity to the 1st Division, $3 \frac{1}{2}$ miles south-west of Bentonville, I received orders from you at 11 o'clock P. M., to march at 2 o' clock on the following morning, in conjunction with the 1st Division, to Bentonville, and there to await further orders.

We started accordingly in the following order:

1. Company of Fremont Hussars;

2. 15th Mo. Vols.;

3. $2 d$ Ohio Battery;

4. The train in the order of respective commands;

5. 1st Division;

6. First Flying Battery;

7. Benton Hussars;

and reached Bentonville at about $40^{\prime}$ clock in the morning, overtaken by you, and as information arrived that the $2 \mathrm{~d}$ Mo. Regiment, of my Division, expected from Smith's Mill, was already near the town, you ordered me to continue the march in the same order to our old camp at Sugar Creek-yourself awaiting the 2d Mo. Regiment, which with the Benton Hussars and the Flying Battery, was to form the rear guard of the column.

I had arrived at your old headquarters on Sugar Creek, with all the troops of the 1st and $2 \mathrm{~d}$ Divisions, except the rear guard mentioned, after $10 \mathrm{o}^{\prime} \mathrm{clock}, \mathrm{A}$. M. ; but while arranging the encampments, the verbal intelligence came that you were attacked and surrounded by a vastly superior force of the enemy at Bentonville. General Osterhaus and myself hastened with all our troops to your relief, and found you still engaged, five miles off, on the Sugar Creek Bentonville road, with the rebel troops, who were speedily routed.

By your order, our forces were drawn up on the Bentonville Sugar Creek road, with all precautions against a fresh attack. But nothing more was heard of the rebel forces, and you effected a junction with the main body on the telegraph r oad at its crossing of Sugar Creek. The Benton Hussars, the Flying Battery, 
the 12 th Mo. and $2 \mathrm{~d}$ Mo. Vols., took a prominent part in fighting their way through the Sugar Creek valley, the last named regiment losing Captain Francis $\mathrm{Kuhr}$, of Company $\mathrm{C}$, a most efficient officer, who was killed in the first attack, when deploying his company as skirmishers. Lieut. Colonel Laibold, commanding the 2d Mo. Regiment, speaks in his official report, of the bravery of Frederick Trensch, Act'g Asst. Adjt. Gen'l of Col. Schæfer's Brigade, and also of Capt. Walter Hoppe, Company K, and Captain Christian Burkhardt, of Co. B, who gave a noble example to the rest of the troops, and I cheerfully make mention of them here.

FrIDAY, MARCH 7TH.-Iutelligence having been received that the enemy was advancing in force, with the view of cutting off our communications with Missouri, and by approaches in other directions, to surround us, General Curtis commanding, ordered a force, composed of parts of all the different Divisions, under command of General Osterhans, to attack him at Leesville, in concert with the $3 d$ Division, under command of Colonel Jefferson C. Davis. The Benton and Fremont Hussars, and the Flying Battery, were directed to join him from my Division.

The 1st Brigade, under command of Colonel Schæfer, and composing the $2 \mathrm{~d}$ and 15th Mo. Vols., with the 2 d Ohio Battery, was directed to take position on the heights this side of tho Sugar Creek Bentonville road, commanding it.

The battle speedily opened, both in the direction, of Leesville and Keetsvills, at Pea Ridge, and raged furiously, withou involving the 1st Brigade of my Division in action. A few skirmishers from the heights, on the opposite side of the valley, and several wounded horses of the rebels, without riders, were all that we saw.

In the afternoon, between 3 and 4 o'clock, however, General Curtis commanding, came personally with the information, that the 4th Division, under acting Brigadier General Carr, on our right, was hard pressed. All the troops were immediately ordered forward, with the exception of the two howitzers of the Ohio Battery, and six companies of the $2 \mathrm{~d} \mathrm{Mo}$. Vols., which were left in their old position on the Sugar Creek Bentonville road.

I, myself, was directed by you to take four companies of the 2 d Mo. Vols., and four pieces of the $2 \mathrm{~d}$ Ohio Battery, forward as quick as possible on the telegraph road, with the view of meeting the remaining force of the 1st and $2 \mathrm{~d}$ Divisions, on the contested battle-ground this side of Elk Horn Tavern.

Arriving there in advance of your troops, I found the 4th Division already exhausted, the enemy pressing forward from the woods around Elk Horn Tavern, to the open space on either side of the telegraph road, with great force, and, seeing that in that critical moment, no time was to be lost, I ordered the $2 d$ Ohio Battery to take position on the left of the road, and replacing the three pieces of the lst Iowa Battery, under command of Capt. M. M. Hayden [this is an error; the 1st Iowa Battery was not under command of Capt. Hayden] to its right, opened at once a brisk and concentrated fire upon the enemy, checking instantly his advance, and at the same time, rallying the partly faltering forces of the $2 d$ Brigade, 4 th Division.

The artillery having kept up a steady fire for half an hour, and perceiving 
that the enemy was forced by it to abandon the woods this side of the tavern, the $2 \mathrm{~d}$ Mo. Infantry, to the right and left of the artillery, was deployed as skirmishers, under Col. Schafer, and advaneed steadily to and through the woods to the fence, within two hundred yards of the Elk Horn Tavern. Thus securing the advance of my artillery, I ordered the 2d Ohio Battery forward, to follow us to a position on and to the left of the road commanding the enemy's stronghold. Sharp flring, and a hard contest was again maintained from this point, until the exemy's Battery was silenced, and the ammunition of the 2d Ohio Battery being nearly exh austed, we retired in good order to our first position, to hold it at all hazards. Night, however. setting in, fighting ceased on both sides, and the four companies of the gallant $2 \mathrm{~d}$ Mo. Vols., were ordered to remain as guard on the extreme line of our centre for the night.

Lieut. Chapman, commanding the $2 \mathrm{~d}$ Ohio Battery, was seriously wounded during the action, and was carried away by the Surgeon. A musket ball passed through my right arm, but did not disable me from continuing in command.

I take here the opportun ity of mentioning the high valor of the $2 \mathrm{~d}$ Mo. Vols. and the $2 \mathrm{~d}$ Ohio Battery, as well as the gallant eo-operation of the 1st Iowa Battery, under Capt. Hayden.

Officers and men all did their duty well and gallantly until the last eartridge was expended.

I have especially to mention the gallant conduct of Col. Schæfer, Lieut. Col. Laibold, and the commander of the $2 \mathrm{~d}$ Ohio Battery, Lieut. Chapman. They nnited coolness to energy and daring.

The 1st Flying Battery of my Division, ordered in the morning to join the Leesville expedition, suffered very severely.

Three of its pieces, under command of Lieuts. Gassen and Schneider, followed by the 1st Missouri and 3d Iowa Cavalry, with the larger portion of the Benton and Fremont Hussars, under command of Col. Bussey, were engaged when the first attack was made upon the enemy's cavalry. The fire of the Battery, forced the enemy to retreat; being, however, attacked from all directions, and not supported by the cavalry, the three pieces were lost, but afterwards found burned, and recovered. Six men of the Flying Battery were killed on this occasion, three wounded, and eight missing.

The rest of the Battery, under command of Capt. Elbert, with a part of the 17th and 15th Mo. Vols., and two companies of the Benton Hussars, under command of Major Heinricks, were guarding the rear of the engaged army, and encountered the enemy about four miles from Sugar Creek, on the Bentonville road. They opened and exchanged fire with them with shell and spherical case shot, until dark, when they retired towards their camps.

The Benton Hussars, who were also, as stated, with the command of Col. Bussey, report that on arriving at the field of contest at $9 \frac{1}{2} o^{\prime}$ clock, A. M., they participated in a momentarily unsuccessful encounter with the enemy; but, that forming again in the first open field, they held it during the remainder of the day, guarding Welfley's Battery.

At $5 \frac{1}{2} o^{\prime}$ clock, P. M., when the rest of the cavalry were withdrawn from the field, the Benton, with two companies of the Fremont Hussars, wero left to maintain it during the night. 
Half the Battalion of Fremont Hussars, under command of Lieut. Howe, were, with the four companies of Benton Hussars, under command of Colonel Nemett; and in the affair just mentioned, Lieut. Clowes and four men were killed, eight wounded, and three missing. The other half of the Battalion, under command of Major Meszaros, charged, as he reports, near the town of Leesville, npon a regiment of the enemy's infantry.

After the enemy had retreated on the left wing, Major Meszaros was ordered, by General Curtis, to take his command to the support of General Carr, but not finding him, was ordered by the commanding General to return to camp.

SATURDAY, MARCH 8TH.-On this day, the battle was resumed at 7 o' clock, A. M., our centre and right having first opened fire (I may say too soon) with a sharp and continuous roturn from the enerny. So severe was their fire, as to imperil our camp, before the 1st and 2d Divisions had taken position on the left. Arriving there, however, the hottest artillery fire was opened, and the whole force moved from position to position, like an immense machine, perfectly irresistable in its progress, under your command. The enemy, severely pressed upon every side, finally fled in wild disorder, leaving large numbers of his dead and wounded upon the ground, the Union army taking immediate possession of his position, and the 1st and $2 \mathrm{~d}$ Divisions pursuing till nightfall, to Keetsville, taking many prisoners, arms and ammunition, and returnitig the next day to our common camp.

On that day of triumph to our arms, the whole of the 1st and 2d Divisions were united upon the open field, in full view of friend and foe, except four pieces of the Ohio Battery, with four companies of the $2 d$ Mo. Vols., of my Division, left as guard in our old position, at Sugar Creek Valley. The two remaining pieces of the Flying Battery, with the Fremont and Benton Hussars, and the 15th Regiment Mo. Vols., were designated as the reserve in the beginning, but were soon drawn into the line of battle, and ordered into action. Six companies of the $2 d$ Mo. Vols., with two howitzers of the Ohio Battery, were sent towards the enemy's extreme right flank, south-west of Elk Horn Tavern, and forming an extreme left. The infantry, deployed as skirmishers, drove the enemy from a thicket at the foot of the hill, and then joined the general advance, the two howitzers of the $2 \mathrm{~d}$ Ohio Battery, in the meanwhile, dismounting the enemy's battery, and driving their infantry from the top of a hill, upon which it had formed. I have to regret that the efficient Swiss regiment, 15th Mo. Vols., whose beautiful flag floated so picturesquely throughout the battle-field, had not the opportunity they so ardently longed for, of following their energetic commander, Col. Joliat, to the heart of the conflict, and of attesting, by their blood, their devotion to the cause.

I feel bound to make honorabie mention of the officers of my staff. They were always at hand, regardless of danger, when duty called them, especially during our desperate attack on the afternoon of the 7th. Lieuts. Gillen and Harken, although for the first time in a severe engagement, stood cooly at my side, under the hottest artillery and musketry fire, while Lieut. Von Unruh, a soldier of European experience, carried my orders, dashing bravely and promptly through every danger. 
Mr. Ullfers, the acesmplished topographical engineer, of my Division, during the arduous campaigns of the last six months, although not called by his especial duties to the battle-field, was every where, regardless of danger, and, while exhibiting an example of cool courage, gathered from the events of the moment, many important features towards his topographical delineation of the battleground.

Major Wiegand, recently of the Garabaldi Guards, who joined me the day before as a Volunteer Aid, also deserves my hearty commendation.

You, yourself, General, having been everywhere, and having seen everything, know how well our men and officers generally behaved. Forward they always moved! Honor to them all!

My report of killed, wounded and missing, is herewith submitted. It shows commissioned officers killed, 3 ; wounded, 3 ; enlisted men killed, 17; wounded, 60 ; missing, 36 .

One hundred and twenty-six prisoners were delivered by Capt. Hesse, Prorost Marshal of the 2d Division, to the grand Provost Marshal, Major Heinricks. A list of their names is herewith submitted.

Over 350 stand of arms, with a large amount of ammunition, and various implements of war, specified by the Division Quartermaster, were also taken, and delivered to Chief Quartermaster Carr. An artillery caisson taken is now with the $2 \mathrm{~d}$ Ohio Battery.

I submit topographical sketches of the extended Pea Ridge battle-field, with our and the enemy's position, on the 7th and 8th of March, prepared by the topographical engineer of my Division, just so honorably mentioned, Mr. Ulfers. The sketch appertaining to your action at Bentonville, will follow in a few days.

I am, General, very respectfully your obd't serv't,

$$
\text { ASBOTH, }
$$

Brigadier Gen'l Comd'g $2 d$ Division.

THE LOSS OF THE SECOND DIVISION.

\begin{tabular}{|c|c|c|c|c|c|c|}
\hline Regiment or Corps. & \multicolumn{3}{|c|}{ Commissioned Officers } & \multicolumn{3}{|c|}{ Enlisted Men. } \\
\hline & Killed. & Wounded. & |Missing.| & Killed. & |Wounded | & Missing. \\
\hline General Officers (Asboth). & (n.............. & $\mid \ldots \ldots \ldots \ldots \ldots . . . . . .1$ & & ................. & ....... & \\
\hline 2d Inf'y Mo. Vols......... & ….........2 & ............. & & ...........6 6 & (...............34 & ..........11 \\
\hline 15th " " & (................... & ......................... & ................... & ................ & ................... & .........11 \\
\hline 2d Battery Ohio Vols................ & .................. & ...................1 & $1 \ldots \ldots \ldots \ldots$ & ...........1 & (.................... & (................. \\
\hline 1st Flying Battery Mo. Vols............ & (................. & (..................... & (n.............. & ….........3 & (.................8 & ….........8 \\
\hline 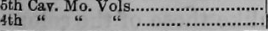 & (................. & 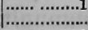 & $\mid$ & $|\ldots \ldots . . .3|$ & $\mid$ & a...........3 \\
\hline Total,$\ldots \ldots \ldots \ldots \ldots \ldots$ & $\mid \ldots \ldots \ldots \ldots .3$ & ....... & |..... & $\mid \ldots \ldots . . .17$ & ....60| & $\ldots . .36$ \\
\hline
\end{tabular}


Copyright of Annals of Iowa is the property of State of Iowa, by \& through the State Historical Society of Iowa and its content may not be copied or emailed to multiple sites or posted to a listserv without the copyright holder's express written permission. However, users may print, download, or email articles for individual use. 